\title{
A very 'prudent integration': white flight, school segregation and the depoliticization of (anti-)racism
}

\author{
Marta Araújo* \\ Centre for Social Studies, University of Coimbra, Coimbra, Portugal
}

This article explores the contemporary legitimation of institutional racism resulting from the prevailing depoliticized framework of integration, which became prominent in the 1960s and is now hegemonic in political and academic debate in Europe. Integration has helped shift the focus to the supposed cultural inadequacies of ethnically marked populations, who ought to show a willingness to pursue the modern dream; simultaneously, it has invisibilized institutional racism and made an antiracist repertoire unavailable. This argument is illustrated through a case of white flight and school segregation in a rural area in Portugal, revealing both the enduring racism against the Roma/Gypsies suppressed and repressed throughout the last five centuries in Europe and its depoliticization within the normal working of institutions. It draws on qualitative research with representatives from public bodies and mediating agents (e.g. teachers and social workers), as well as on analysis of the official reports by the Portuguese state and European institutions.

Keywords: institutional racism; the politics of integration; white flight; school segregation; Roma/Gypsies

\section{Introduction}

Since the 2000s, European monitoring bodies have emphasized that the Roma ${ }^{1}$ are particularly disadvantaged and vulnerable (ECRI 2011) and the population most discriminated against (FRA 2009; CoE, FRA, OSCE/ODIHR 2011). Yet a historically informed approach that engages with the institutional-ization of racism and the production of difference - capable of overcoming their construction as idiosyncratic - has largely been absent from academia and policymaking. Although the historicity of Roma institutional discrimina-tion in Europe is not completely unknown or ignored, insufficient analytical engagement with racism as a historical and political process (Essed 1991; Goldberg 1993) results in their reification as 'noble savages' (Brearley 2001) or anti-modern heroes, ill-equipped to fit modern institutions and values - thus paving the way for interpretations of inequality as inevitable. In my view,

*Email: marta@ces.uc.pt 
this is being sustained by the hegemony of integration as a political and conceptual framework.

Calls for the integration of ethnically marked populations are not neutral. The underlying assumptions of integration impose certain diagnoses and solutions to the problem being framed: as argued throughout the article, the focus is on the cultural inadequacies of marked populations - who ought to show a willingness to integrate to prevent hostile reactions. Integration thus acts pre-emptively by ruling out the routine pragmatics of racist governance (Hesse 2004, 144) and making an anti-racist repertoire unavailable. This will be illustrated with a case regarding white flight and the segregation of Gypsy students in Portugal. Yet this is not an article about them (Nimako 2012) the Roma/Gypsy population - but about the framing and tackling of situations of racism within the policy agenda of integration. This is an important inflection: there is now what has been called a minority research industry that inscribes the denial of racism within the production of knowledge (by naturalizing hostility, exceptionalism and resistance to the term racism, the defence of presumed national values and self-victimization [Essed and Nimako 2006, 297-304]). Significantly, this industry tends to blur and benefit from the relation between policy, politics and scholarship (Essed and Nimako 2006, 281). In Portugal, minority research is particularly evident in studies about the Gypsies: updating nineteenth century Gypsology, ${ }^{2}$ such academic endeavours scrutinize almost every aspect of their lives and inform particular policy approaches. ${ }^{3}$ In contrast, the focus of this research has been the discur-sive practices and the operation of established and respected forces in the society' (Carmichael and Hamilton 1967, 20), namely decisionmakers and professionals in integration initiatives, contributing both to the political invisibility of racism and to the visibility ${ }^{4}$ of the Gypsies as pathological and unfit.

The article draws on research within a comparative European project which proposes a historically and contextually sensitive approach focusing on the semantics of (anti-)racism as shaped by public bodies and policies, as well as civil society organizations, on a European, national, regional and local level. ${ }^{5}$ Case studies in education aimed to unravel how schools are framing and tackling situations of ethno-racial discrimination. The empirical work on Portugal was carried out mainly between April and August 2011 via semi-structured interviews with 20 participants: nine representatives of public bodies (on education, interculturality and equality), seven members of civil society organizations (on integration and anti-racism), two municipal workers (including one cultural mediator), and two former teachers at the segregated school. Public bodies' representatives were selected due to their high profile and availability; other participants were known to have professional knowledge on the case and were selected using a snowball strategy. Three participatory workshops with academics, decision-makers, grass-roots and political activists were also carried out to discuss research findings and 
recommendations. Key European and national policy documents published since the early 2000 s were analyzed, and the national and local press was monitored.

\section{The Roma: in, but not of Europe}

In many countries, including England under Henry VIII, it became a capital offense to be a Rom. If caught, a Rom could be tortured, flogged, branded, and banished. If caught a second time, the penalty was death for men and women. In some countries such as the Netherlands, organized Gypsy hunts became fashionable. Male Gypsies would be sent to the royal galleys, chained as oarsmen for decades or even for life. In Hungary, Germany, Spain, and England, Gypsy children as young as 2 or 4 were taken by force and given to non-Gypsies to rear $[\ldots]$ what has been called 'sustained genocidal persecution' of Roma stemmed from the highest authorities, from kings and popes. (Brearley 2001, 589)

'Born in, but not of' Europe (Goldberg 2009, 167), the Roma have been targeted by a considerable amount of legislation since the sixteenth century. From the Renaissance to the eighteenth century, legal instruments ensured their expulsion and extermination and, subsequently, the 'forcible assimilation and eradication of the Romany language and identity' (Brearley 2001, 589). While the 'sustained genocidal persecution' of Roma has diminished since the nineteenth century, it has nevertheless been accompanied by their construction as 'noble savages' (Marinaro and Sigona 2011) and by their racialization:

By the late nineteenth century, at the height of British imperialism, British scholarship had racialized the Gypsies of England as non-Anglo-Saxon as well as non-European. ... The discourses of Gypsology were then linked to the colonial discourses of Orientalism as scholars searched for congruences between the racial, linguistic and cultural attributes of Gypsies on the one hand, and various populations of India on the other (Helleiner 1995, 540).

In Portugal, legal discrimination since the early sixteenth century regulated the terms of Gypsy presence in the Kingdom - which included death and deportation to the colonies (namely Angola and Brazil) for 'unwillingness' to assimilate:

I, the King, make known to those who see this law that, because experience has shown that the dispositions of the Ordinations of the Kingdom and other subsequent Laws, and several orders that in different times were approved so that the Gypsies do not enter the Kingdom and stay in their Lands [...] have decided in good faith, and hereby command, that no person in this Kingdom of either gender shall use the costume, language, or Geringonça of the Gyp-sies [the name given to the language spoken by the Gypsies] [...] and that the socalled Gypsies, or people treated as such, shall not dwell together in 
more than two houses in each street, nor walk together in the streets, or halt together in them, or in the fields, and shall not sell or buy, or exchange beasts, unless they use the costume, language, and lifestyle of other people in the Land ... (D. João V, Ordination No. 28, 10 Nov. 1708, in Coelho 1892, 256257 , author's translation)

The history of legal discrimination of the Gypsy population has been noted since at least the late nineteenth century (e.g. Coelho 1892), with more recent publications emphasizing that laws continued to explicitly discriminate in democratic Portugal until the end of the twentieth century (e.g. Bastos, Correia, and Rodrigues 2007). ${ }^{6}$ Racism has become inscribed within the working of institutions, requiring no specific legislation against this popula-tion - merely failing to act on existing hierarchies of privilege within the normalcy of the 'racial state'. As argued by David T. Goldberg (2002), 'A state may license racist expression within its jurisdiction simply by turning a blind eye, by doing nothing or little to prevent or contest it, by having no restricting rules or codes or failing to enforce those on the books' (114). Yet mainstream academic and political approaches in Portugal have failed to develop historically sensitive approaches that can engage with the long-lasting patterns of institutionalized racism in democratic contexts. Rather, racism has been sustained in three interrelated ways: (1) reinforcing difference by empha-sizing Gypsies' non-Europeaness; (2) naturalizing racism as common-sense prejudice; (3) scrutinizing Gypsy populations' ability/willingness to integrate.

First, regarding the pervasive re-drawing of difference, Helleiner (1995, 541-542) noted how the linguistic study of Romani, in the late nineteenth to the early twentieth century, tested the Indian origin theory of Gypsies - impacting on national imaginaries and claims for political belonging. Contem-porary studies in the genetic of populations continue to emphasize distance by tracing the foreign ancestry of the Roma to the same 'distant source'7: 'the Indian subcontinent' (Goldberg 2009, 180). The constant search for Gypsies' origins - a population in Europe/Portugal for over five centuries - begs the question of how many generations it must take for one to be seen as a national/European. Academic and political accounts stressing their non-Europeaness help to naturalize racism as a set of understandable reac-tions of fear and hostility by the 'majority' population (e.g. Mendes 2005; GACI/ACIDI 2011). This is particularly evident in the official statement by the Gypsies Communities Support Cabinet, depicting this population as exotic and strange (i.e. not properly Portuguese) and naturalizing racism:

... the Gypsies have wandered throughout national territory for a long time, since the mid-fifteenth century $[. .$.$] we can imagine the strangeness that this$ people - so different, talking an unknown language, which non-Gypsies called geringonça (caló), dressed in an exotic fashion and with totally differ-ent habits - caused in the society then. It is quite likely that the immediate reaction was rejection and persecution, which came to be embodied in laws 
that inflicted sometimes quite harsh punishments. (GACI/ACIDI 2011, n.p., author's translation)

Second, fleeting references to the history of discrimination against the Gypsies act as a mere disclaimer (van Dijk 1993, 76-84), together with an inadequate analytical understanding of racism within the paradigm of prejudice studies (Henriques 1984). Racism is thus interpreted as 'feelings of mutual distrust' (PORTUGAL 2013, 3), and the discriminatory legal mechanisms that have existed throughout the history of Europe tend to be naturalized as a response to the mentalities and anxieties of people in those times (GACI/ACIDI 2011) - overlooking the 'complicity by those in positions of leadership' in Europe (Brearley 2001, 594) in dehumanizing the Roma/ Gypsies and sustaining their 'vulnerability' throughout the centuries.

Third, the consequences of the historicity of racism have been often evaded in explanations of contemporary discrimination: mainstream accounts tend to approach difference as already constituted and shift the focus to scrutinizing 'Gypsy culture' - questioning its ability and willing-ness to accept modern institutions and values:

the devaluation of and disinvestment from school knowledge cuts across a great part of the [Gypsy] population (independently of their financial resources), the majority of whom still do not express any interest in school as an institution, which might be explained by reference to the existence of an habitus of ethnicity. (Casa-Nova 2002, 107, emphasis in original; see also Rosário, Santos, and Lima 2011).

These academic and political endeavours - by continuously marking Gypsy populations and policing ontological distinctions between hosts and settlers - contribute to endlessly deferring the possibility of assimilation/integration (Sayyid 2004, 150-153). The problem is framed as the contrast between a naturally dominant national culture and the not-so-modern 'Gypsy culture' that ought to show a willingness to be modernized in order to become comprehensible (Santos 2007) - it is assumed that full integration would automatically follow. Disregarding these crucial ideas to understand the contemporary renewal of racism, such academic and policymaking approaches equate existing inequalities with (self-inflicted) social exclusion.

Overall, the role of the state and academia is consigned to that of responding to the eternally 'relatively incomplete' (PORTUGAL 2013, 24) picture of the situation of 'Gypsy communities' and their 'specificities'. Importantly, the most vocal denunciations by political and grass-roots activists - suggesting that despite the increasing amount of information and funded initiatives on the integration of this population a change in approach has not come about - are excluded from the production of such knowledge: 
The conclusion I arrive at is, here we go. ... It's my people, they bring money. 'No, No. They are very excluded! We need to have three social work-ers, we need a professional in psychopedagogy, we need a psychologist and a string of little guys to work with these people who are facing such discrimi-nation in ...' When very often these [Gypsy] people have abilities, they are independent, willing to change and willing to move forward. (Albertina, Gypsy grass-roots activist)

\section{Sit down next to me? The return to integration as policy reform}

Compared to other groups, Roma people have lower life expectancy. They have poorer health and live in worse housing. Employment and education levels are abysmal and of little concern to the politicians, whose commitment to change is at best weak, and most of the time non-existent. Like black Americans, Roma know the indignity of segregated schooling. (Rustem 2010, n.p.)

Policies aiming at the inclusion of Roma people respect and realise the core values of the European Union, which include human rights and dignity, nondiscrimination and equality of opportunity as well as economic development. (EC 2011,3)

While nowadays pervasive across Europe, the integration approach became prominent as a domestic policy in the US and Britain in the 1960s. A third way between conflictive race relations and coercive assimilation drawing on functionalist sociology, integration - as a descriptive and normative term was poorly defined and inadequately discussed from the outset (Small 1994).

Integration draws on a particular tradition in politics and in the social sciences that became dominant with UNESCO (1950, 1951, 1964, 1967) interventions in the concept of 'race' through the involvement of the academic community. UNESCO's recommendation of its replacement by 'ethnicity' as a descriptor of difference decoupled 'race' from culture (Lentin and Titley 2011), giving centre stage to cultural difference through notions such as relativism and pluralism (Füredi 1998). This took place in a context marked by Anglo-American diplomatic efforts to deflect racial consciousness and mobilization. ${ }^{8}$ Evading 'race'/power, the idea of difference linked, rather than opposed, segregation and integration:

... the concept of difference [...] helped provide an intellectual rationale for segregation and apartheid. [...] At a time when demands for civil rights were increasingly heard in the United States, and when Soviet Union manifestos about the goal of racial equality were finding a resonance in the international community, the insistence on the right to difference has a distinctive apologetic air. Internationally, the demand for equal rights far outweighed the right to difference. (Füredi 1998, 225) 
The rise of integration within the political debate in the US took place in the context of the consolidation and amplification of the black movement's struggles. Concessions to the acquisition of civil rights in the early 1960s within a reformist agenda - alleviated but did not substantially challenge white supremacy after Jim Crow America (Fredrickson 2000). A strategy of incorporation of rights meant accommodating demands within the status quo, i.e. formal equality of opportunity as the desirable horizon (Winant 2001, 150-169):

... as the [black] movement agenda came to be accepted in the suitably moderate form - of equal opportunity legislation and the withdrawal of support for official policies of segregation - the more radical movement critique of the embeddedness of racial dynamics through U.S. society was cast aside. (Winant 2001, 165)

Significantly, the critiques of the politics of integration and the idea of institutional racism as embedded in liberal democracies voiced by grass-roots movements at the time, although marginal, are still relevant today. In his influential 1966 Black Power speech, Stokely Carmichael (aka Kwame Ture) denounced the 'thalidomide drug of integration' for failing to challenge power inequalities involving the distribution of resources. Integration acted as 'a subterfuge for the maintenance of white supremacy' by naturalizing racism (Carmichael 1966, n.p.). The notion of institutional racism was proposed to contest the dominant view of individual racism (see Henriques 1984), being 'less overt, far more subtle, less identifiable in terms of specific individuals committing the acts. But it is no less destructive of human life [...] [it] originates in the operation of established and respected forces in the society, and thus receives far less public condemnation' (Carmichael and Hamilton 1967, 20). ${ }^{9}$ The shortcomings of integration were also evident in the debates following the Brown v. Board of Education case, outlawing racial segregation in US public schools. The virulent reaction of those benefitting from established privilege meant that the 1970s debate on integration through bussing focused more on 'black kids sitting next to white kids', than on the 'inequitable distribution of resources' (Eddings, Thornton, and Murray 1997, 2). Even in the 1980s, integration - understood as 'good race relations'- often did not entail white support for equality, especially when this meant the redistribution of resources or affirmative action (Small 1994, 149).

In Britain, debates on integration also emerged in the mid-1960s, marking the Labour Party's attempt to reform assimilationist policies and coming to operate as 'the absorption and negation of black discontent: the accommodation within the local status quo of factors that threaten the status quo, the expansion of the status quo itself to accommodate such factors' (Sivanandan 1976-2008, 84-85). This occurred as the integration agenda 
shaped 'the subsequent tendency to interpret social relations in terms of cultural relations' (Brandt 1986, 94), while shifting the focus onto the ethnically marked populations: 'any failure on the part of the social policy was read as the "failure" of "immigrants" to integrate, thus making it clear that the onus was on them.' (95). Discourses within this framework conceded that equal opportunities did not yet exist (Gillborn 1990, 146). Nonetheless, the debate on institutional racism was systematically eluded via the culturalization of politics, that is, 'the reduction of political motivations and causes to essentialized culture' (Brown 2006, 20), producing enduring understandings and explanations of inequality, social relations and political conflict. When transposed to the domestic terrain, it relocated 'the pathologies of racism' as 'the pathologies of the immigrant' and the ethnically marked (Sayyid 2004, 154). The onus thus shifted to the objects of integration: 'conform or else' (Gillborn 2008, 83). When integration made a political comeback in Britain - following public reaction to $9 / 11$ in the US, the $7 / 7$ bombings in London and grass-roots movements' denunciation of Islamophobia - it repeated 'the historical trick of projecting minoritized communities, rather than white racism, as the problem' (Gillborn 2008, 82).

While integration has proved to be an ineffective antidote to racism, it has maintained a high-status in European political and academic agendas, shaping institutional intervention. This can be seen in the approach by European institutions to non-European migrants (e.g. EC 2005; EC/MPG 2011) and to the Roma. A number of policy documents calling for a panEuropean approach to the integration/inclusion ${ }^{10}$ of Roma has been issued in the last decade, ${ }^{11}$ marked by: (1) the acknowledgment of discrimination in access $^{12}$ to key spheres (education, employment, healthcare and housing) and the need to introduce/reinforce the monitoring of discrimination and segregation (EC 2010, 2011); (2) the linking of the requirement for nondiscrimination policies and measures to the defence of European shared values, i.e. universal human rights, the rule of law, tolerance, nondiscrimination and equality (CEU 2011; EC 2010, 2011); (3) the increasing emphasis on raising awareness as a means of counteracting prejudice and misunderstanding (EC 2011, 2013a). Significantly, the acknowledgment of everyday discrimination goes hand-in-hand with an approach that frames racism as exceptional to Europe.

The EU Framework for national Roma integration strategies, published in 2011, called for the outlining of national plans as an unprecedented commitment by EU Member States to promoting the inclusion of Roma on their territory' lasting until 2020 (EC 2012, n.p.). The Framework proposed that 'the social and economic integration of Roma is a two-way process which requires a change of mindsets of the majority of the people as well as of members of the Roma communities' (EC 2011,2). Similarly, in Portugal the term integration is deployed in the strategy as the solution to 'mutual 
distrust': 'majorities" stereotypes and Gypsies' 'obedience to internal codes of conduct' and 'resistance to relocation and education' (PORTUGAL 2013, 10) - raising doubt and 'blaming the victim' (Troyna 1993):

It is imperative to overcome the feeling of mutual mistrust between the majority of the population and Roma communities. In this sense, the majority must embrace diversity and adopt a more inclusive attitude, by respecting Roma traditions and values, while Roma communities must be made aware of the need to observe the essential principles and obligations entailed by living in a state governed by the Rule of Law, in order to fully benefit from Portuguese citizenship and all the rights associated therewith. (PORTUGAL 2013, 3)

Throughout the document, discrimination is perceived as the misapplication of equality before the law, resulting from 'prejudice', 'negative judgements' (30), and 'lack of knowledge' (55), and prevented by raising 'public awareness' (28). Inequalities are not denied, but framed as 'difficulties in integration' (45), with the Gypsies being portrayed as 'idiosyncratic' - a term deployed in the Portuguese version (56) - requiring 'cultural change':

... strategies aimed at promoting better access to employment are required, as well as initiatives aimed at improving the technical and social skills of these minorities, suited to their specific nature and lifestyles. Success in this area can only be achieved by encouraging cultural change and supporting the crea-tion of new employment positions or businesses. (55)

Gypsy populations are thus main targets of policy interventions, while existing social and legal structures and arrangements are consecrated. The section on discrimination (PORTUGAL 2013, 27-28) is revealing of the official approach to racism: ${ }^{13}$ outlining no specific measures or aims besides awareness-raising activities, it shields itself in the principles of equality of treatment and non-discrimination in the Constitution and in the Universal Declaration of Human Rights; the universality of their application and antiracism as embedded in the national political culture/Western values are taken for granted. Significantly, the document downplays the 2000 EU Racial Equality Directive, which emerged following political consensus that racism had not vanished from European democratic states.

In sum, integration operates by alluding to discrimination while making the victims of racism suspect of the 'reactions' they face. On the one hand, Gypsies are required to show willingness to integrate - i.e. assimilate, forego of traditional habits and resistance to modern institutions, such as schools. On the other, the majority society is to be made aware of their prejudices within a moral approach to anti-racism that evades power inequalities, as analyzed elsewhere (Maeso and Araújo, 2014). 


\section{Segregate now, integrate later: legitimating racism in school}

\subsection{The segregation of Gypsy students in Portugal: denunciations and denials}

[Regarding the 'Roma community'] Portugal does not recognize the existence of national minorities in its territory [...] We would have to disagree with paragraph 62 , which states that attitudes of rejection and hostility towards minorities are present in the Portuguese society, for this does not accurately reflect the rule in the Portuguese society. (Portuguese representative at the CoE 2007, n.p.)

The existence of second-class education provisions for Roma students and situations of school segregation have been widely reported across Europe. Since the early 2000s, the European Monitoring Centre on Racism and Xenophobia (EUMC 2002, 30) acknowledged school segregation in several Member States - later conceding that it was 'a common phenomenon in large parts of the EU' (EUMC 2006, 14; FRA 2007; 2008) - targeting Roma pupils and often associated with spatial segregation (EUMC 2004a, 22). Segregated schooling was considered the result of decisions by school staff, parental pressure and 'freedom of choice' (EUMC 2002) - allowing children to enrol in schools outside their catchment area (EUMC 2003, 177), ${ }^{14}$ a process known as white flight. ${ }^{15}$ Not necessarily explicit on the grounds of 'race'/ethnicity (EUMC 2002), school segregation is considered direct discrimination - 'individual acts and institutional practices of a racist and xenophobic character' (EUMC 2005, 65) which take different forms: intraclass, intra- and inter-school segregation (69). By the mid-2000s, EUMC periodic reports on Portugal noted the 'absence of any complaints filed by Roma' (EUMC 2006, 45), 'acute spatial segregation' (66), low academic success and high dropout rates (79). Two cases of segregation were highlighted:

... in 2002, it was reported that one class in an elementary school consisted of 18 Black pupils from Guinea [Bissau] and one Roma who had to attend this class during two consecutive years. After protests, the school defended itself with the argument of 'fortuitous occurrence', further stating that origi-nally, the class even had had two white pupils but they applied for a transfer and that there was nothing the school could do about it. In the year 2000, a similar case found a deeper echo in public opinion since an important national newspaper published it. A school in the Central Region assembled all its Roma pupils in one class. This decision led to a controversial discussion and was highly disputed by the Central Region Teachers' Union, which caused the Ministry of Education to intervene and break up the class. In a statement the Ministry of Education declared that it does not allow 'any racial discrimination practices or attitudes within the educational system'. (EUMC 2004b, 117) 
School segregation was noted in several regions of the country, mostly in rural areas (in larger cities, spatial segregation and school choice tend to ensure segregated education).

The European Commission against Racism and Intolerance and the Council of Europe further emphasized the long history of education policies that 'can lead either to assimilation or to segregation of Roma and Traveller children at school on the grounds that they [are] "socially and culturally handicapped"' (CoE 2009, 46-56; see also ECRI 2006, 4). Accordingly, the $\mathrm{CoE}$ has called on its Members States to 'take urgent measures, including legal and political ones' to end both inter- and intra-school segregation (ECRI 2011, 5). While reporting several situations, the four reports published on Portugal (ECRI 1998, 2002, 2007, 2013) do not name cases of segregation as such, but as a series of (isolated) incidents: ${ }^{16}$

ECRI is especially concerned to learn that Gypsy children are occasionally faced with hostile reactions from parents of non-Gypsy children who do not wish Gypsy children to join their own children's classes. For example, ECRI notes the incident widely reported in the press of the transfer of ten or so Gypsy children from a school in Teivas to a school in Rebordinho at the start of the 2003 school year. The children were transferred apparently in response to pressure from non-Gypsy parents in the first school. Placards were put up in the new school stating 'No to Gypsies'. Nonetheless, the school officials reported the incident to the police and, according to ACIME [High Commission on Immigration and Ethnic Minorities], the authorities did everything to ensure that the Gypsy children could attend their new school under acceptable conditions. (ECRI 2007, 30)

In spite of these denunciations by European institutions, the Portuguese national strategy on Roma integration does not consider situations of school segregation as an education policy priority, measure or target (PORTUGAL 2013, 45-50, 71-74), fleetingly mentioning that 'Mixed classes (including Roma and non-Roma students) [...] are likely to endear schools to Roma communities' (47). Although an EC review of the draft strategy had recommended: 'More focus on desegregation and ensuring that mainstream policies also respond to the specific needs of Roma' (EC 2013b, 1), the final document approved by the Portuguese state remained silent on this. The case presented below illustrates the need to tackle school segregation seriously and the conspicuous official denial of racism in a context marked by the absence of monitoring mechanisms on ethno-racial discrimination and the lack of an independent equality body (ECRI 2007; FRA 2008).

\subsection{A case study on white flight and school segregation}

The case of school segregation and white flight studied in a rural area in Portugal lasted over a decade. ${ }^{17}$ In 1997/1998, some Gypsy families enrolled their offspring at the Aguda primary school, complying with the 
1996 requirement that the children of beneficiaries of the Guaranteed Minimum Income attended compulsory schooling. Later that year, a separate class was formed for the late schooling of Gypsy pupils over 13 years old (described as a 'Year Zero'), taught 20 kilometres away at a local association. In 2000, objections by non-Gypsy parents at Aguda and their negotiation with the Regional Education Authority resulted in the formation of a segregated class with the remaining 10 Gypsy students at the nearby Ferrarias village school. The national media denounced the case. According to a news report, the head teacher argued that it was the first time that Gypsies attended this school and there should be 'prudency' in their integration; this was a temporary solution aimed at preventing clashes and preparing the children for 'full integration'. The decision was backed by the Regional Education Authorities, ${ }^{18}$ in light of 'children's own special characteristics'. Although a parent interviewed for a newspaper conceded that the non-Gypsies 'opposed' the inclusion of Gypsy students in the same classes as their children, the head teacher and the Local Education Authorities denied any external pressure in making this decision, presented as pedagogi-cal in nature. The news further reports that the Ministry of Education toler-ated the situation as it would serve to diagnose the learning difficulties of the pupils concerned, stating that it would not allow any instances of racial discrimination. Only a Teacher's Union representative and the Romani Union president used the terms 'segregation' and 'discrimination' to refer to the events.

Later, in 2003, some Gypsy pupils were transferred from Ferrarias to Aguda primary school, followed by a process of white flight. According to the High Commission for Immigrants and Ethnic Minorities, whose intervention was required, the transfer was made according to the 'will and need' of the guardians of the children involved. By the school year 2006/2007, the Aguda school had two forms: one for Gypsy and another for non-Gypsy pupils. The remaining non-Gypsy parents organized a demonstration, locking and closing Aguda, and transferred their children to other schools in the area. From 2007 to 2010, only Gypsy pupils attended Aguda: initially, four to eight pupils simultaneously; with the transferral of other Gypsy pupils from schools in the area to the primary school it totalled 14. Aguda was a case for closure, following the 2005 national policy requiring the shutting down of primary schools with less than 10 pupils (or less than 20 in cases of low attainment). Acting within their powers, the Regional Education Authorities suggested to the Ministry of Education that the school was an exceptional case and it remained open. It was only in 2010, after a resolution of the Council of Ministers (44/2010) requiring the closure of all primary schools with fewer than 21 pupils, that Aguda was shut down. Research presented here focused on the period in which the school remained segregated, and enquired about how situations of racism were framed and tackled. 


\subsubsection{Marking the Roma as culturally inadequate for schooling}

In most of the interviews held with teachers, social workers and decisionmakers, segregation was abstractedly considered undesirable, but tolerated due to the pupils' 'special characteristics'. The pathologization of the Gypsies was evident in the interviewees' uncritical acceptance and rein-forcement of key assumptions about this population, combining resistance and inability to adjust to school norms and values and poor social and cul-tural skills. Regarding the former, the following examples are representative of their perceived 'lacks': 'lack of interest in education' (Dora, teacher); 'lack of motivation', 'lack of rules' and 'resistance to work', (Ticha, tea-cher); 'lack of abstract skills and the ability to project themselves into the future' (Maria, social worker); 'practically illiterate', 'difficulties following timetables', 'behaviour problems' and 'indiscipline' (Carina, social worker); 'acquiescing in absenteeism' (Manuela, education decision-maker). Regard-ing poor social skills, understood as culturally based, abundant stereotypes of bad manners, poor personal care and hygiene continuously marked difference. This is in line with other research that pointed to the deployment of racist categories and vocabularies with regard to the Roma such as 'unfit', 'workshy', 'inferior', and 'anti-social' (Baar 2008, 380). The data collected suggested that the presumed Gypsy traditions were interpreted as culturally inadequate and this was made pedagogically relevant:

Some of the things I learned from working with the Gypsies, at least with this community in particular, is that - we cannot fool ourselves - that most, and there are a few exceptions, take two or three years at least to learn how to read and write $[\ldots]$ Because, for instance, there were children with nothing, with no books. ... The school had to offer them books and they only worked during the time they were there, they wouldn't even take the books home, because if they took them home, they would not be returned as they should. They would be dirty or spoilt. There was no support at home, nothing; the books weren't even taken home [...] The Gypsy community, they don't have a culture of schooling, they aren't interested, they were there because they had to be, or because somebody told them that that if they didn't go to school the Social Inclusion Income could be cut [...] I think that the parents don't see school as something of value that can give them a better future; they don't have a culture of schooling and don't see schooling this way. (Dora, teacher, emphasis added)

These perceptions are not held by deviant racist individuals: the idea that the 'Gypsy culture' rejects the value of education actually pervades much academic work, even when disclaiming intentions to generalize (e.g. CasaNova 2006):

... what distinguishes most Gypsies from Gadges, wherever we look at the former, is the choice of subsistence economy, self-employment or some combination of both (Acton 1974, 252ff.) These forms of existence demand a 
kind of socialization different from the one offered by the school, something visible in the frequent complaints on the inability of this institution to foster in young people a sense of initiative, entrepreneurial vocation, abilities for independent work, etc. (Enguita 2004, 203)

Moreover, this is not merely a matter of 'biased representations' as the wide circulation and reification of negative views of the Gypsies informed professional decisions that affected pupils' school trajectories and life chances.

\subsubsection{Tolerating white flight and trivializing racism}

Following a demonstration by non-Gypsy parents against the presence of the Gypsies, the former removed their children from Aguda. At the time, the school's catchment area was determined by parents' home or work-place. ${ }^{19}$ Although it is not clear how parents counteracted existing legisla-tion, no obstacles seem to have been posed to the transferral:

Nobody tells me or convinces me that the families who flew from Aguda to enroll in another [school] all went working immediately in another location in the same neighbourhood [freguesia], that's a lie. So someone allowed it to be done. And therefore, allowed one, allowed the other, until everyone ... went and the [Gypsies] stayed. (Maria, social worker)

A debate at the Municipal Assembly in early 2007 revealed that the authorities, with a view to 'future integration', sanctioned white flight and segregation:

I recall that it [Aguda] received intervention from the Municipality, estimated at about 100 thousand euros, creating all the conditions to be attended by about 14 to 15 youngsters of Gypsy ethnicity that have there their adequate education. It is often not worth to hide the situation, but the truth is that by placing these children there in the initial stages of integration with other children, all the other parents removed their children and they enrolled them in schools nearby. This made the Regional Director of Education see that closing the school would jeopardise [...] the balance that had been achieved for a minority that was finally starting to receive integration measures and attitudes, [and] the further dispersal of students [...] the Regional Director was surprised and, at the same time, safeguarded this circumstance of alleged exceptionality. (President of the Municipal Assembly)

In the first term of 2007/2008, a school visit by the General Inspectorate of Education reported that running a school with 'five Gypsies only' was a 'barrier to their full integration'; yet no action was taken. ${ }^{20}$ Despite the fact that the aims of this research were made clear (that is, that this was a study on racism) and that many of the participants asked were known for their commitment against discrimination, they did not challenge the non-Gypsy parents' decision to transfer their children, which breached existing school 
enrolment legislation. Instead, observations on the distinctiveness (i.e. inferiority) of 'the Gypsy culture' naturalized and legitimated segregation and white flight:

[After being asked why she thought white flight occurred, the teacher replied] I would be speculating, because I have no concrete grounds. But I think that it has a lot to do with, with hygiene, because it really is not easy. And they often told stories about when they came into contact with these kids, even at lunchtimes, for instance, that they don't have those ... they had no ... They didn't use a knife and fork, so there were some kids who were very shocked and even disgusted. Also, there were some thefts, some things disappeared that might have just been lost ... but then they were seen as being taken by those pupils. That tough intolerance among the pupils, physical conflicts between them during breaks as well. I think these are among the reasons. (Ticha, teacher)

The case studied was a textbook example of racism; yet despite the amount of data gathered on the construction of the Gypsy population as undeserving of immediate integration, the only time that racism was ever mentioned by the interviewees was when they surmised how this population had interpreted the situation: either as self-proclaimed victims or as perpetrators of so-called reverse racism. Significantly, when these research findings were discussed with the Ombudsman Office $^{21}$ in 2012, racism was trivialized with arguments on the lack of intention to discriminate and marked populations playing the race card:

Victor: I mean, it's not the same as the school's public services saying, 'Well, I have 20 Portuguese and 10 Gypsies, rather than putting them together, no, I'll make one form for the Portuguese and another for the Gypsies.

Catarina: No, in that case it was only the school ...

Victor [interrupting]: No, but what I'm saying is, there were those 30 pupils: the 20 Portuguese were leaving, the other 10 stayed!

Catarina: Nothing can be done about it, right?

Luísa: There are two factors to consider: one, it's because with the social insertion benefit one of the things they have to do is be in school, point number one. Point number two, is the particular difficulty, regardless of the social benefits, of bringing Gypsy children into the school, because of the community they live in. What is preferable? You [addressing the researchers] must know the answer to that. What is preferable? Is it having children in school, giving them schooling, educating them, instructing them, or simply sticking with the 20 Portuguese and leaving out the Gypsies? [...]

Victor: [Complaints by Gypsies] are not really significant. [...] We have, as Paulo said, I mean ... often the complaint has a cause, but to reinforce this claim they add in, or even start off with, I'm ... I'm black, I'm whatever. ... 
But the complaint is exactly like any other complaint by a white citizen. Simply that whoever complains of being in the same circumstances, has suffered the same behaviour ... from the police, for instance ... always puts in race to strengthen the complaint, which is exactly the same as any other.

Luísa: Self-discrimination. They discriminate on the basis of race too.

Victor: Exactly. They allege discrimination to reinforce the complaint. That's common.

This is further evidence that playing the race card is an idea increasingly deployed in relation to ethnically marked populations rather than merely in electoral politics (Lentin and Titley 2011, 76). Moreover, by accusing the Gypsies of crying 'racism' as an excuse for their 'unwillingness to inte-grate', change was expected from them. At Aguda, for instance, teachers encouraged pupils to overlook racism and change their own behaviour instead:

... if they [the Gypsy pupils] saw someone looking at them, they didn't react well either, 'What are you looking at me for?' [...] And I used to say, 'Oh Sofia, you can't act like that. If I, the teacher, see someone looking at me, I'm not going to react or say anything much, what I do is ignore it and that is what you ought to do.' (Dora, teacher)

... the pupils were out there, playing in the playground, and someone passed by, and there were accusations on both sides. Intolerance. 'We did not offend the mister, we were singing but in our language, but the person in the road, on the other side of the gate, thought we were insulting him, so there was a slanging match.' Okay, we just had to deal with the issue, right? 'So we have to pay attention too. People don't understand, they might be misled into thinking that you are intolerant too, and so we'll prevent that by you playing there, at the back of the school rather than here.' (Ticha, teacher)

\subsubsection{Integration as cure}

Integration measures found for the pupils once Aguda was closed combined bussing, cultural celebration, and training for everyday life. Fuelled by a belief in 'prudent' integration, the dispersal of pupils to different schools and classes 'with no more than two or three Gypsy pupils' (Dora, teacher) was ensured to 'control misbehaviour' (Carina, social worker), and to pre-vent them 'getting together' (Isabel, social worker) or 'joining forces' (Maria, social worker). That is, as a strategy of social control - preventing mobilization - rather than with a view to desegregation. So-called inter/multicultural education $^{22}$ was proposed at the new school the pupils were to attend. Interviewees were confident that the activation of difference via "the positive side, of joy' (Maria, social worker) - celebrating 'Gypsy music and dance' (Isabel, social worker) - would achieve 'acceptance' and 'tolerance'. 
This liberal, 'benevolent multiculturalism' (Troyna 1993) - epitomized by the multicultural festival - aimed to increase students' 'self-esteem' by celebrating the exotic and reinforcing difference, without calling for structural change and tackling unequal access to material and symbolic resources (Essed 1991). Finally, older pupils were enrolled on a programme designed to help them complete compulsory schooling with professional certification. This is considered 'an exceptional remedial measure' applied when young people and their families have 'rejected other existing [measures] both in the education system and in professional training, or after they have been rejected' (PETI 2011, n.p.). The failure to question key assumptions in such interventions (e.g. 'rejection of education') and the kind of activities promoted reveals the low expectations ascribed to these students:

[We] had a weekly session aimed primarily at valuing the school and promoting active citizenship. We chose a set of actions that we organized into themes, so that one month we worked on food, another month on health, road safety ... (Isabel, social worker)

In short, integration as a solution far from succeeded in reversing the racist assumptions at the root of segregation and actually contributed to the legitimation of racism through the culturalization of social relations and political conflict.

\section{Conclusion}

In Portugal fewer than one out of 10 Roma is reported to have completed upper-secondary education. (ECRI 2013, 22)

Prominent as a reformist policy, the integration framework has broadly failed to challenge the continuing dominance of six decades of tried-and-failed Eurocentric approaches to racism in liberal democracies (Hesse 2004). Integration as a conceptual framework assumes the boundedness of notions such as culture, society and community, shaping the debate in important ways. On the one hand, the notion of a presumed original homo-geneity of national societies (Goldberg 2009) into which ethnically marked populations must integrate maintains unchecked prevailing ideas of the nation state and national belonging, Europe and Europeaness (Hesse 2007). On the other, it perpetually re-inscribes difference - reinforcing the ethni-cally marked as not belonging to Europe - and naturalizes racism as natural prejudices and fears of the (pathological) newcomer (Henriques 1984). The culturalist and depoliticizing logic of integration thus paves the way for the concealment and legitimation of the privilege of unmarked whiteness, pre-cluding the debate on racism as a political struggle (denunciations are often framed as playing the race card). 
Contemporary integration approaches to the Roma/Gypsies have not been able to break with this logic. Two interrelated aspects are worth emphasizing from the case study. First, the case was illustrative of the em-beddedness of racism within the normal working of institutions. At the level of public authorities (e.g. education authorities and municipalities), there was a failure to stop the process of white flight although legislation on school enrolment at the time providing the framework to do so. Segregated schooling, both within Ferrarias school and at Aguda, was also allowed to take place for many years despite existing legislation against ethno-racial discrimination. At the local level, teachers and social workers involved in integration programmes reproduced racism not only through the re-making of stereotypes drawing in their everyday practices, but also by inertia: i.e. not questioning or even pointing to institutional structures, regulations and procedures that helped to maintain racism and school segregation out of the spotlight $^{23}$ - despite having professional knowledge on the situation. Overall, the lack of an anti-racist framework to tackle situations of discrimination is revealing, despite much official integration and interculturality rhetoric (Araújo 2013).

Second, the case also shows how the integration agenda helped framing the question as the 'Gypsy problem': non-Gypsy parents counteracting existing legislation to soothe their racism-fuelled 'fears' was seemingly considered less problematic than perceptions of Gypsies' manners and culture, seen as clashing with 'our ways' and thus requiring change. The abundance of stereotypes constructing the Gypsies as not having 'a culture of school-ing' (i.e. not fitting modern institutions) legitimated their nomadic school enrolment - at the will of local non-Gypsy families - to whom the privilege of decision was granted. The pathologization of the Gypsy population thus contributed to: (1) pre-empting the possibility of discussing racism within school structures, arrangements and practices that continuously consecrate white privilege (McIntosh 1989) and maintain inequalities in access to resources (shaping the possibility of 'school choice') and in outcomes; (2) making their denunciations of racism illegitimate by implying that the victims had too much at stake to articulate an unbiased judgement. Institutional actors, on the contrary, constructed themselves as committed professionals with no particular interests to defend. The case is thus illustrative of the tacit compliance with the privilege of an ethnically unmarked population.

At present, the history of racism of the Roma/Gypsies continues on the making. Despite European and national political recognition of their dismal situation, integration as a framework contributes to this by evading 'race'/ power. This points to the pressing need to develop critical approaches that question how the enduring patterns of discrimination that this population has experienced in Europe and their exclusion from ideas of Europeaness and national belonging have constantly produced and reified difference, policing the boundaries of what is a Roma/Gypsy (see Scott 1967; Helleiner 
1995; Sigona 2009). Only thus can we move beyond an approach that condemns this population to the position of objects of integration in policy and research, rather than political subjects struggling for equality. Despite the amount of scholarship and funded initiatives to target this population, it is mostly outside the reach of the state and academia that the anti-racist struggle goes on:

I think the main issue is power [...] It's not in their [those in positions of power] interest to touch on certain issues. They know perfectly well that what is going on is racism, that a certain word is racist, that they are racist. But they are not interested, that's the power they have and we have to fight it. And it can't be changed easily [...] They simply don't want to touch [racism]. That's the big problem. Because many problems could be solved if there was a completely dif-ferent policy. We know that. So we're here to talk about it. But the problem is that. Essentially people don't want to mess with things. They want to find names, create names for the problems, create ... 'This is not a matter of racism, that is ...' They know how to turn institutions around, they know how to turn people around. (Pedro, Gypsy grass-roots activist)

\section{Acknowledgements}

I would like to thank the participants in this research for taking their time to collaborate in this project. I would also like to thank Silvia R. Maeso for the continuing exchange of ideas and Olivier Guiot for his assistance throughout the TOLERACE project.

\section{Funding}

The research on which this article draws received funding from the European Union's Seventh Framework Programme (FP7/2007-2013), under grant agreement no. 244,633 .

\section{Notes}

1. The term Roma is nowadays most commonly used and endorsed by the Council of Europe. While the term 'Gypsy' was rejected by activists at the First World Romani Congress in London in 1971 (Liégeois 1994, 258), it has been used by grass-roots movements to assert national belonging in Portugal. I thus deploy the term Roma generally, and Gypsy when referring to the Portuguese context, using the original term in English documents.

2. See Helleiner (1995).

3. e.g. the collection Looks (Olhares) published by the High Commissariat for Immigration and Intercultural Dialogue (www.acidi.gov.pt/banco-de-informa cao/comunidades-ciganas, accessed 26 August 2013).

4. See Brighenti (2007) for a discussion of the concept of in/visibility.

5. TOLERACE - The Semantics of Tolerance and (Anti)Racism in Europe: public bodies and civil society in comparative perspective (2000-2013). Further information: www.ces.uc.pt/projectos/tolerace 
6. In 1985, article 81 of the ordinance $722 / 85$ subjected the 'nomads' - understood as targeting the Roma/Gypsy - to 'special surveillance' by the police; although contested, this was considered constitutional by the Portuguese Constitutional Court in 28 June 1989 (Bastos, Correia and Rodrigues 2007).

7. e.g. Mendizabal et al. 2011.

8. In face of anxieties over the perceived declining role of the West in international relations and the Cold War, 'race' was a potential pressure point for transnational mobilization between the Communist Bloc, the Third World and the US black movement, as analysed by Carmichael (1966), Füredi (1998), Fredrickson (2000), Winant (2001) and Hesse (2004).

9. See Hesse (2004) for a genealogy of the concept.

10. These two terms are often used interchangeably: 'integration' and 'inclusion' both refer to measures for improving the situation of Roma living in the Member States 'territories' (CEU 2011, footnote to page 1).

11. e.g. the Strasbourg Declaration on Roma (CoE 2010), the EU Framework for national Roma integration strategies (EC 2011), and the 10 Common Basic Principles on Roma Inclusion (EC 2010).

12. Equality for the Roma/Gypsies is often framed in terms of access to public services and goods.

13. Racism is a term absent from the document; the only section in which 'cultural/racial discrimination' is deployed is that on Gender Equality (PORTUGAL 2013, 32).

14. i.e. parental 'avoidance strategies' to prevent their children attending schools in their catchment area (FRA 2011, 57).

15. The term white flight was popularized in 1970s debates on desegregation in US public schools, due to the significant number of white families moving to the suburbs to avoid integrated schooling.

16. In some EC documents, racist school segregation is framed as immigrant clustering' (e.g. EC/MPG 2011, 133).

17. Events were reconstituted through data collected in interviews, as well as in the media and official documents. For the sake of confidentiality, references to the latter were omitted and all names of places and people were changed throughout the article.

18. Regional Education Authorities (Decree-Law 141/93), had little autonomy and acted as decentralized services of the Ministry of Education (Decree-Law 208/ 2002). Local Education Authorities (CAE) were in charge of overviewing and supporting the functioning of schools at local level. Both were meanwhile extinct.

19. Dispatches $373 / 2000,14,026 / 2007$ and 13,170/2009. Since 2012, legislation encourages the 'right to freedom of choice' (Dispatch 5106-A/2012).

20. Later the school received weekly support from the state-sponsored Choices Programme (Escolhas) for the social inclusion of youth 'at risk', mostly ethnically marked populations. In early 2010, the programme promoted 'contact' between Gypsy and non-Gypsy pupils, with weekly visits from the former to another school.

21. With powers to deal with complaints of unfair or illegal actions or omissions by public authorities.

22. Interviewees used these terms interchangeably, opting more frequently for multiculturalism.

23. Since segregation occurred in the smaller village of Aguda, it never featured again in the press. 


\section{References}

Araújo, Marta. 2013. "Challenging Narratives on Diversity and Immigration in Portugal: The (De)Politicization of Colonialism and Racism." In Migrant Marginality: A Transnational Perspective, edited by J. A. Capetillo, G. Jacobs, and P. A. Kretsedemas, 27-46. New York: Routledge.

Baar, H. V. 2008. "The Way out of Amnesia?" Third Text 22 (3): 373-385.

Bastos, José G. P., André Correia, and Elsa Rodrigues. 2007. Sintrenses Ciganos: Uma Abordagem Estrutural-Dinâmica [Gypsies from Sintra: A StructuralDynamic Approach]. Sintra: CMS, Mimeo.

Brandt, Godfrey. 1986. The Realization of Anti-racist Teaching. London: Falmer Press.

Brearley, M. 2001. "The Persecution of Gypsies in Europe." American Behavioral Scientist 45 (4): 588-599.

Brighenti, A. 2007. "Visibility: A Category for the Social Sciences." Current Sociology 55 (3): 323-342.

Brown, Wendy. 2006. Regulating Aversion. Tolerance in the Age of Identity and Empire. Princeton: Princeton University Press.

Carmichael, Stokely. 1966. "The Black Power Speech at Berkeley - California." Accessed February 17, 2013. http://www.edchange.org/multicultural/speeches/ stokely_carmichael_blackpower.html

Carmichael, Stokely, and Charles Hamilton. 1967. Black Power: The Politics of Liberation in America. New York: Vintage.

Casa-Nova, Maria José. 2002. Etnicidade, Género e Escolaridade [Ethnicity, Gender and Schooling]. Lisbon: IIE.

Coelho, Adolpho. 1892. Os Ciganos de Portugal: Com um Estudo Sobre o Calão

[The Gypsies of Portugal: With a Study on Jargon]. Lisbon: Imprensa Nacional. CoE, FRA, OSCE/ODIHR. 2011. Joint Statement on International Day for the Elimination of Racial Discrimination, 21 March. Strasbourg, Vienna, Warsaw: CoE, FRA and OSCE/ODIHR.

CoE (Council of Europe). 2007. "Comments of the Government of the Portugal on the First Opinion of the Advisory Committee on the Implementation of the Framework Convention for the Protection of National Minorities by Portugal'." Accessed September 10, 2011. www.coe.int $/ \mathrm{t} / \mathrm{dghl} /$ monitoring/minorities/3_fcnm docs/PDF_1st_Com_Portugal_en.pdf

CoE (Council of Europe). 2009. Recommendations Adopted by the Committee of Ministers of the Council of Europe on Roma and Travellers. Strasbourg: Council of Europe.

CoE (Council of Europe). 2010. 'The Strasbourg Declaration on Roma': Council of Europe High Level Meeting on Roma, Strasbourg, 20 October 2010. Strasbourg: Council of Europe.

CEU (Council of the European Union). 2011. Council Conclusions on an EU Framework for National Roma Integration Strategies up to 2020. Brussels: CEU.

EC/MPG. 2011. Handbook on Integration for Policy-makers and Practitioners. 3rd ed. Brussels: Directorate-General Justice, Freedom and Security.

ECRI. 1998. First Report on Portugal. Strasbourg: Council of Europe.

ECRI. 2002. Second Report on Portugal. Strasbourg: Council of Europe.

ECRI. 2006. General Policy Recommendation No. 10 on Combating Racism and Racial Discrimination in and through School Education, Adopted 15 December. Strasbourg: Council of Europe.

ECRI. 2007. Third Report on Portugal. Strasbourg: Council of Europe. 
ECRI. 2011. Recommendation No.13 on Combating Anti-gypsyism and Discrimination Against Roma, Adopted 24 June. Strasbourg: Council of Europe.

ECRI. 2013. Fourth Report on Portugal. Strasbourg: Council of Europe.

Eddings, J., J. Thornton, and B. Murray. 1997. "Second Thoughts about Integration." U.S. News \& World Report, 07/28/97 123 (4): 32.

Enguita, M. F. 2004. "School and Ethnicity: The Case of Gypsies." Pedagogy, Culture \& Society 12 (2): 201-216.

Essed, Philomena. 1991. Understanding Everyday Racism. Newbury Park, CA: Sage.

Essed, P., and K. Nimako. 2006. "Designs and (Co)-incidents: Cultures of Scholarship and Public Policy on Immigrants/Minorities in the Netherlands." International Journal of Comparative Sociology 47: 281-312.

EUMC. 2002. Annual Report. Vienna: EUMC.

EUMC. 2003. Migrants, Minorities and Employment. Vienna: EUMC.

EUMC. 2004a. Annual Report. Vienna: EUMC.

EUMC. 2004b. Migrants, Minorities and Education. Vienna: EUMC.

EUMC. 2005. Annual Report. Vienna: EUMC.

EUMC. 2006. Annual Report. Vienna: EUMC.

EC (European Commission). 2005. A Common Agenda for Integration Framework for the Integration of Third-country Nationals in the European Union. Brussels: EC.

EC (European Commission). 2010. 10 Common Basic Principles on Roma Inclusion. Brussels: EC.

EC (European Commission). 2011. EU Framework for National Roma Integration Strategies. Brussels: EC.

EC (European Commission). 2012. National Strategies. Accessed July 3. http://ec. europa.eu/justice/discrimination/roma/national-strategies/index_en.htm

EC (European Commission). 2013a. Proposal for a Council Recommendation on Effective Roma Integration Measures in the Member States. Brussels: EC.

EC (European Commission). 2013b. The European Union and Roma - Country Factsheet. Accessed June 6, 2014. http://ec.europa.eu/justice/discrimination/files/ roma_country_factsheets_2013/portugal_en.pdf

FRA. 2007. Annual Report. $\bar{V}$ ienna: FRA.

FRA. 2008. Annual Report. Vienna: FRA.

FRA. 2009. EU-MIDIS at a Glance - Introduction to the FRA's EU-wide Discrimination Survey. Vienna: FRA.

FRA. 2011. Annual Report. Vienna: FRA.

Fredrickson, George M. 2000. The Comparative Imagination: On the History of Racism, Nationalism, and Social Movements. Berkeley: University of California Press.

Füredi, Frank. 1998. The Silent War: Imperialism and the Changing Perception of Race. London: Pluto Press.

GACI/ACIDI. 2011. "História E Cultura Do Povo Cigano." Accessed August 25. http://www.ciga-nos.pt/Default.aspx?tabindex=2\&tabid=17

Gillborn, David. 1990. 'Race', Ethnicity and Education. London: Routledge.

Gillborn, David. 2008. Racism and Education: Coincidence or Conspiracy? London: Routledge.

Goldberg, D. T. 1993. "Modernity, Race, and Morality." Cultural Critique 24: 193227.

Goldberg, David Theo. 2002. The Racial State. Malden, MA: Wiley-Blackwell.

Goldberg, David Theo. 2009. The Threat of Race. Malden, MA: Wiley-Blackwell. 
Helleiner, J. 1995. "Celts and Tinkers: Colonial Antecedents of Anti-traveller Racism in Ireland." Ethnic and Racial Studies 18 (3): 532-554.

Henriques, J. 1984. "Social Psychology and the Politics of Racism." In Changing the Subject: Psychology, Social Regulation and Subjectivity, edited by J. Henriques, W. Hollway, C. Urwin, C. Venn, and V. Walkerdine, 60-90. London: Routledge.

Hesse, B. 2004. "Discourse on Institutional Racism: The Genealogy of a Concept." In Institutional Racism in Higher Education, edited by I. Law, D. Phillips, and L. Turney, 131-147. Stoke on Trent: Trentham Books.

Hesse, B. 2007. "Racialized Modernity: An Analytics of White Mythologies." Ethnic and Racial Studies 30 (4): 643-663.

Lentin, Alana, and Gavan Titley. 2011. The Crises of Multiculturalism: Racism in a Neoliberal Age. New York: Zed Books.

Liegeois, Jean-Pierre. 1994. Roma, Tisgannes, Voyageurs. Strasbourg: Conseil d'Europe.

Maeso, Silvia Rodríguez, and Marta Araújo. 2014. "The Politics of (Anti-)Racism: Academic Research and Policy Discourse in Europe." In Racism and Sociology

- Racism Analysis|Yearbook 5, edited by W. Hund and A. Lentin, 207-237. Berlin: LIT

Marinaro, Isabella, and Nando Sigona. 2011. "Introduction: Anti-gypsyism and the Politics of Exclusion: Roma and Sinti in Contemporary Italy." Journal of Modern Italian Studies 16 (5): 583-589.

McIntosh, P. 1989. "White Privilege: Unpacking the Invisible Knapsack." Accessed March 1, 2013. http://www.isr.umich.edu/home/diversity/resources/white-privi lege.pdf

Mendes, Maria M. 2005. Nós, Os Ciganos e Os Outros - Etnicidade e Exclusão Social [We, The Gypsies and The Others - Ethnicity and Social Exclusion]. Lisboa: Livros Horizonte.

Mendizabal, Isabel, Cristina Valente, Alfredo Gusmão, Cíntia Alves, Verónica Gomes, Ana Goios, Walther Parson, et al. 2011. "Reconstructing the Indian Origin and Dispersal of the European Roma: A Maternal Genetic Perspective." PloS One 6 (1): e15988.

Nimako, K. 2012. "About Them, but Without Them: Race and Ethnic Relations Studies in Dutch Universities." Human Architecture: Journal of the Sociology of Self-knowledge 9: 45-52.

PETI. 2011. Programa PIEF. Accessed September 10. http://www.peti.gov.pt/pe eti menu.asp?menuID $=7$

PORTUGGL. 2013. National Roma Communities Integration Strategy 2013-2010. Lisbon: Council of Ministers Resolution 25/2013.

Rosário, Edite, Tiago Santos, and Sílvia Lima. 2011. Discursos do Racismo em Portugal [Discourses of Racism in Portugal]. Lisbon: ACIDI.

Rustem, R. 2010. Why Martin Luther King Matters to Europe's Roma. Accessed September 10, 2011. http://www.ertf.org/en/component/content/article/3-news flash/149-why-martin-luther-king-matters-to-europes-roma.html

Santos, B. S. 2007. "Abyssal Thinking from Global Lines to Ecologies of Knowledges." Review XXX (1): 45-89.

Sayyid, S. 2004. "Slippery People: The Immigrant Imaginary and the Grammar of Colours'." In Institutional Racism in Higher Education, edited by I. Law, D. Phillips, and L. Turney, 149-159. Institutional Racism in Higher Education. Stoke-on-trent: Trentham Books.

Scott, M. 1967. "What is a Gypsy?" Race \& Class 9: 93-95. 
Sigona, Nando. 2009. “"Gypsies out of Italy!” Social Exclusion and Racial Discrimination of Roma and Sinti in Italy." In Italy Today: The Sick Man of Europe, edited by A. Mammone and G. Veltri, 143-157. London: Routledge.

Sivanandan, A. (1976) 2008. "Race, Class and the State: The Political Economy of Immigration." In Catching History on the Wing, edited by A. Sivanandan, 6589. London: Pluto Press.

Small, Stephen. 1994. Racialised Barriers: The Black Experience in the United. States and England. London: Routledge.

Troyna, Barry. 1993. Racism and Education. Buckingham: Open University Press. van Dijk, Teun. 1993. Elite Discourse and Racism. Newbury Park, CA: Sage.

Winant, Howard. 2001. The World is a Ghetto: Race and Democracy Since World War II. New York: Basic Books. 